\title{
Implementasi Bela Negara di Era Teknologi Dalam Pembelajaran Pendidikan Kewarganegaraan
}

\author{
Auli Ihza Ahyati ${ }^{1}$, Dinie Anggraeni Dewi ${ }^{2}$ \\ ${ }^{1,2}$ Pendidikan Guru Sekolah Dasar, Universitas Pendidikan Indonesia \\ Jl. Pendidikan No.15, Cibiru Wetan, Cileunyi, 40625, Bandung, Jawa Barat, Indonesia \\ 13auliihza@upi.edu
}

\begin{abstract}
State defense and national resilience is an attitude that every citizen must have. Because every citizen, especially the younger generation, is the next generation of continuity in the life of the nation and state, therefore it is necessary to be well prepared and structured to become a developed country. State defense has a very important relationship in realizing the goals of a country itself. In the 1945 Constitution, article 27 and article 30 paragraph (1), namely regarding the rights and obligations of every citizen in efforts to defend the state and efforts to defend national security. It is necessary to instill and implement an attitude of state defense, especially among the younger generation through the existence of civic education subjects. Seeing the increasingly advanced technology era, it has had several negative impacts on national resilience as well as the waning attitude of defending the state among millennials today. Therefore, seeing the problems and challenges that will be faced in the future will be more varied and complex, therefore it is necessary to have an attitude of defending the country and its implementation in direct life. This article will present the results of research on the implementation of state defense in Citizenship Education learning. This article describes state defense activities that must be implemented in any circle, whether elementary, junior high, high school, university. Furthermore, the material in this work can be used as a reference in making curricula, as well as rules and policies regarding state defense.
\end{abstract}

Keywords: implementation of state defense, the importance of civic education

\begin{abstract}
Abstrak
Bela negara dan ketahanan nasional merupakan suatu sikap yang harus dimiliki oleh setiap warga negara. Karena setiap warga negara terutama generasi muda merupakan generasi penerus keberlangsungan dalam kehidupan berbangsa dan bernegara, oleh karena itu perlu disiapkan dengan baik dan tersusun untuk menjadi negara yang maju. Bela negara memiliki hubungan yang sangat penting dalam mewujudkan tujuan suatu negara itu sendiri. Pada UUD 1945 pasal 27 dan pasal 30 ayat (1) yaitu tentang hak dan kewajiban setiap warga dalam upaya bela negara dan upaya pertahanan keamanan nasional. Perlunya menanamkan dan melaksanakan sikap.bela negara..terutama di kalangan generasi muda melalui adanya mata pelajaran pendidikan kewarganegaraan. Melihat era teknologi yang semakin maju membawa beberapa dampak negatif bagi ketahanan nasional serta memudarnya sikap bela negara dikalangan milenial saat ini. Oleh karena itu melihat permasalahan dan tantangan yang akan dihadapi kedepannya akan semakin variatif dan kompleks, maka dari itu diperlukan sikap bela negara dan implementasi nya di kehidupan secara langsung. Artikel ini akan memaparkan hasil penelitian mengenai implementasi bela negara dalam pembelajaran Pendidikan Kewarganegaraan. Artikel ini memaparkan kegiatan bela negara yang harus diterapkan di kalangan apapun baik SD, SMP, SMA, Perguruan Tinggi. Selanjutnya, materi di dalam karya ini dapat dijadikan salah satu refensi dalam membuat kurikulum,maupun aturan dan kebijakan tentang bela negara.
\end{abstract}

Kata kunci : implementasi bela negara, pentingnya pendidikan kewarganegaraan

Copyright $\odot 2021$ Aulia Ihza Ahyati, Dinie Anggraeni Dewi

$\triangle$ Corresponding author: Aulia Ihza Ahyati

Email Address: 13auliihza@upi.edu (Jl. Pendidikan No.15, Cibiru, Wetan, Cileunyi, Bandung)

Received 22 March 2020, Accepted 24 April 2020, Published 30 April 2021

\section{PENDAHULUAN}

Negara Kesatuan Republik Indonesia merupakan negara yang memiliki sejarah yang berbeda dari bangsa lainnya, perjalanan sejarah tersebut meliputi pra kolonialisme dan kolonialisme. Pada masa 
pra kolonialisme yaitu masa kejayaan kerajaan-kerajaan yang memiliki perjuangan berbeda. Masa kolonialisme adalah masa dimana Indonesia di jajah dalam hal sumber daya, baik sumber daya alam maupun sumber daya manusia (Suwarno, 2011: 18). Pada masa itulah timbul kesadaran dan rasa patriotisme, rela berkorban dan cinta tanah air. Pada saat ini mengalami masa yang berbeda dengan masa sebelumnya tentunya tantangan dan kesulitan yang dialami pun berbeda dengan masa yang lalu. Maka setiap warga negara menjadi penerus dimana negara ini akan tetap maju dan berkembang serta dapat melindungi negara ini. Membela negara merupakan salah satu tindakan atau upaya setiap warga negara dalam menghadapi tantangan, tantangan yang dimaksud yaitu mencakup permasalahan problem ideolgi, ekonomi, sosial budaya, dan keamanan.

Perkembangan teknologi saat ini lebih mengarah pada era digital dimana terus berkembang. Teknologi sendiri saat ini telah digunakan oleh manusia untuk mempermudah melakukan setiap pekerjaan dan tugasnya, serta menjadi alat yang membantu berbagai kebutuhan manusia. Dalam jurnal Kris W, M Fahrid (2018) menyattakan bahwa Pada era digital atau teknologi ini tentunya membawa berbagai perubahan baik positif maupun negatif, namun dapat kita lihat saat ini era teknologi tentunya lebih membawa dampak negatif terutama pada ketahanan bangsa. Dampak negatif tersebut masuk melalui berbagai bidang seperti politik, ekonomi, sosial budaya, pertahanan, keamanan, dan teknologi informasi itu sendiri.

Teknologi yang semakin canggih membawa perubahan yang sangat besar pada setiap kalangan, kemudahan dalam mengakses teknologi memberikan kebebasan yang tidak terkendali. Telah terjadinya revolusi digital sejak 1980an dengan perubahan teknologi mekanik, dan analog ke teknologi digital dan terus berkembang hingga saat ini, perkembangan teknologi ini cenderung lebih masif setelah adanya teknologi baru dan tentunya lebih canggih (wawan, 2017). Di era teknologi saat ini menjadi ancaman yang besar bagi bangsa oleh karena itu diperlukannya pendidikan kewarganegaraan dalam upaya mengatasi ancaman yang ada. Pendidikan adalah suatu system yang mengembangkan misi cukup luas, yaitu berkaitan dengan perkembangan fisik, perkembangan psikologis dan perkembangan sosial dalam ber iteraksi dengan lingkungan sekitar.

Setiap warga negara sendiri mempunyai hak dan kewajiban dalam mempertahankan keutuhan bangsa terutama pada sikap bela negara. Perlunya penanaman kesadaran bela negara untuk menghadapi setiap ancaman yang akan terjadi, baik ancaman militer maupun non militer. Upaya pembelaan negara yang berupa sikap, tekad, dan tindakan warga negara yang teratur termasuk dalam sikap bela negara berdasarkan pelaksanaaan pendidikan kewarganegaran. Kesadaran berbangsa dan bernegara pada setiap warga sangat diperlukan serta keyakinan pada pancasila dan UUD 1945 dalam melaksanakan hak dan kewajiban bela negara. Bela negara sendiri memiliki arti upaya pertahanan dan keamanan (pasal 27 dan pasal 30 ayat 1), bela negara sendiri sudah diatur dalam perundang- undangan (I nengah, 2019: 47). Pembelajaran bela negara juga tercantum dalam materi pendidikan 
kewarganegaraan dimana pada setiap jenjang nya sudah diajarkan untuk bela negara dalam bentuk, cinta tanah air, menaati peraturan, dan melestarikan budaya.

Pendidikan kewarganegaraan merupakan mata pelajaran yang memiliki tujuan atau visi sebagai pendidikan yang memiliki nilai demokratis, pendidikan moral, pendidikan sosial dan masalah pendidikan politik saat ini merupakan salah satu mata kuliah wajib, dalam pengembangan pribadi setiap mahasiswa (Endang, 2019). Pendidikan kewarganegaraan sendiri memiliki tujuan yaitu menjadikan masyarakat atau warga negara yang baik, mendukung bangsa dan negara, cerdas, berkeadaban dan bertanggung jawab. Era yang terjadi saat ini adalah era teknologi dimana kemajuan dan masuknya informasi dari luar mempengaruhi tingkah laku atau perilaku masyarakat saat ini terutama dalam sikap patriorisme dan cinta tanaha air. Adanya pendidikan kewarganegaraan dalam beberapa ancaman yang ada diperlukan implementasi, salah satu implementasi guna mempertahankan pertahanan bangsa adalah mengimplementaskan bela negara, hal ini sangat diperlukan oleh berbagai kalangan tidakhanyak pelajar maupun pendidik.

Pembelajaran pendidikan kewarganegaraan ini digunakan untuk melatih setiap peserta didik agar mampu menilai berbagai macam masalah sosial, ekonomi, politik, secara cerdas dan bertanggung jawab agar setiap permasalahan yang tidak bernilai tersebut dapat dihindarkan. Menurut Suharyanto (2013: 192) mengatakan bahwa salah satu bentuk pendidikan kewarganegaraan bela negara untuk warga bertujuan agar masyarakat,,dapat,,diandalkan,,oleh bangsa dan,,negara. Menurut Gredinand dalam Asep dkk. (2020: 131) menyatakan bahwa saat ini pendidikan kewarganegaraan sedang terjadi kendala dalam menemukan mengimplementasikan sikap untuk menciptakan warga negara yang mempunyai cinta tanah air, rela berkorban, sadar akan berbangsa dan bernegara, dan setia kepada ideologi bangsa yaitu pancasila, hal tersebut merupakan suatu pondasi atau awalan untuk menumbuhkan rasa bela negara yang dilakukan baik secara fisik maupun nonfisik. Sebagai negara yang berkembang tentunya kemajuan teknologi juga semakin berkembang, baik dalam aspek kehidupan, informasi dan pendidikan (Wawan, 2017).

Pendidikan kewarganegaraan sudah menjadi mata pelajaran atau mata kuliah yang wajib diikuti oleh setiap peserta didik, adapun tujuan dari pendidikan kewarganegaraan menurut beberapa ahli. Menurut Abdul Aziz dan Sapriya dalam buku perndidikan kewarganegaraan untuk pergurun tinggi (2012: 311) mengatakan bahwa "tujuan pendidikan kewarganegaran adalah untuk menjadikan atau membentuk sikap warga negara yang agar menjadi lebih baik”. Menurut SK Dirjen Dikti.nomor 43/2006, tujuan pendidikan,,kewarganegaraan yang dimaksud adalah untuk,,menjadikan dan,,meningkatkan,,peserta..didik dalam keilmuannya mengenai berbangsaan bernegara, memiliki rasa cinta tanah air, berdisiplin dan berpartisipasi aktif dalam membangun kehidupan bernegara yang mengikuti aturan atau dasar ideologi bangsa yaitu pancasila.

Kesadaran dari bela negara merupakan hal yang sangat diperlukan terutama dalam sikap moral dan pengimplementasinya sehingga dalam kehidupan yang berlangsung dapat memperkuat pertahanan 
bangsa dalam ancaman paham radikalisme. Dalam dunia perkuliahan mengatassi ancman paham radikalisme ini melalui beberapa mata kuliah yaitu, pendidikan pancasila dan pendidikan kewarganegaraannya (Muwamanah, 2017: 61).

Dalam jurnal (Suwarno, 2011: 20) meningkatkan rasa dan sikap bela negara di dasari dengan adanya sikap nasionalisme, sikap nasionalisme ditimbulkan dengan rasa cinta pada tanah air, meningkatkan rasa persatuan antar warga negara serta rasa kesediannya dalam melanjutkan masa kini dan masa yang akan datang dengan berlandaskan kebersamaan dan dapat mewujudkan cita-cita bangsa ini.

\section{METODE}

Metode penelitian yang digunakan dalam penelitian ini yaitu kualitatif dengan menggunakan metode kuesioner, yaitu degan memberikan beberapa pertanyaan melalui media google form dimana responden diminta untuk menjawab pertanyaan tersebut. Penelitian kualitatif deskriptif ini digunakan untuk mengidentifikasi setiap permasalahan dan memaparkan pendapat mengenai pentingnya bela negara agar dapat pemahaman yang mendalam (Septiana, 2020). Lokasi pada penelitian ini yaitu berada di Sidoarjo, Jawa Timur. Informan penelitian menggunakan purposif sampling dengan memilih informan yaitu Mahasiswa/Mahasiswi, generasi milenial, masyarakat umum. Data peneltian dikumpulkan dengan menggunakan kuisioner yang diisi oleh respondem melalui media dan teknik pengumpulan data.

\section{HASIL DAN DISKUSI}

\section{Peran Pendidikan Kewarganegaraan}

Pelaksanaan pendidikan kewarganegaraan sangat diperlukan dan penting dalam meningkatkan kesadaran kewarganegaraan setiap masyarakat baik kalangan siswa maupun umum. Karena PKN sendiri memiliki tujuan yaitu civic education yang memiliki fungsi dan peranan sebagai pendidikan kewarganegaraan (Asep, dkk, 2020 :131). Adanya pembeelajaran PKN dalam dunia pendidikan bertujuan untuk mempersiapkan peserta didik agar menjadi masyarakat yang baik, yang memiliki komitmen atau landasan dasar dalam mempertahankan kesatuan dan persatuan Indonesia. Saat ini pembelajaran PKN merupakan mata pelajaran wajib yang diajarkan di dunia sekolah. Materi yang terdapat didalamnya diharapkan mampu memberikan pemahaman kepada setiap pelajar atau peserta didik, agar dapat meningkatkan kesadaran kewarganegaraan peserta didik serta mendorong peserta didik untuk meng implementaskan nilai-nilai kewarganegaraan dikehidupan sehari-hari.

Menurut Farida $(2017,71)$, Dalam pembelajaran pendidikan kewarganegaraan tentunya memiliki tujuan sendiri atas materi dan pembelajaran yang hendak disampaikan. Berikut tujuan dari pendidikan kewarganegaraan adalah berupa visi, misi dan kompetensi yaitu: 
1. Pendidikan Kewarganegaraan di perguruan tinggi tentu memiliki visi tersendriri yang berisikan yaitu sebagai sumber nilai dan menjadi sebuah pedoman atau landasa dalam menyelenggarakan studi. Visi yang harus dimiliki mahasiswa adalah intelektual, religius, kesadaran bernegara dan rasa cinta tanah air pda bangsannya.

2. Misi dari pendidikan kewarganegaaraan adalah,,untuk,,membantu,,mahasiswa dalam menetapkan dan meyakinkan kepribadiannya agar dapat berjalan dengan konsisten serta mampu mewujudkan nilai nilai dasar pada pancasila.

Fungsi dari pembelajaran PKN itu sendiri untuk membangun kesadaran kewarganegaraan yaitu bela negara teritama kesadaran pada setiap pribadi manusis, fungsi tersebut sudah tercantum dalam Undang-Undang Negara Republik Indonesia 1945 pasal 30 ayat 1 yang menyatakan bahwa "tiap- tiap warga berhak dan berkewajiban dalam ikut serta dalam upaya pertahanan dan ketahanan nasional

\section{Pembahasan}

\section{Implementasi bela negara di era teknologi}

Bela negara bukan hanya tugas aparat keamanan negara seperti TNI, POLRI, namun tanggung jawab setiap warga negara termasuk generasi muda di era teknologi ini. Perspektif bela negara bukan hanya mengenai "angkat senjata" dan "pertempuran" namun berbagai ancaman secara nonfisik pun dapat dirasakan saat ini. Asep dkk (2020), menjelaskan ancaman terbesar bangsa ini adalah mengacu pada jati diri bangsa dengan merusak generasi muda saat ini melalui perkembangan teknologi yaitu masuknya narkoba, vidio porno, (HIV/AIDS), hoaks dan radikalisme serta terorisme. Dalam penelitian terhadap 20 responden yang terdiri dari mahasiswa serta masyarakat umum terdapat 94,7\% mengetahui apa itu bela negara dan 5,3\% kurang mengetahui apa itu bela negara. Dalam pengertian dan pemahaman responden ialah rasa cinta terhadap bangsa atau negara sendiri dan akan melindungi dari berbagai ancaman yang mengganggu keamanan negara. Bela negara dapat disebut sebagai sikap serta perilaku atau tindakan setiap warga negara yang dilakukan secara teratur, menyeluruh serta dijiwai oleh kecintaan kepada NKRI yang berdasarkan pada Pancasila dan UUD 1945 dalam menjamin kelangsungan hidup Bangsa dan Negara, bentuk dari sikap bela negara adalah rela berkorban demi bangsa dan negara, membela harga diri bangsa, menjaga eksistensi bangsa. Bela negara juga dapat dilakukan dengan cara belajar sungguh-sungguh (Bagus, 2006).

Kemajuan teknologi paa saat ini membawakan dampak negatif yang paling signifikan dan terasa dalam kehidupan, yaitu: Pertama, ancaman pelanggaran hak kekayaan intelektual HKI, karena mudahnya dalam mengakses informasi serta menyebabkan maraknya plagiarisme. Kedua, ancaman terhadap pikiran pada pribadi anak yang cenderung lebih bepikir praktis namun tidak kritis. Ketiga, menurunnya moralitas pada anak sehingga terjadinya tindak kejahatan kriminalitas. Keempat, tidak dapat memanfaatkan waktu yang disediakan, seperti waktu belajar siswa yang cederung anak lebih suka bermain game online (Wawan, 2017).

Diagram lingkaran pada Gambar 2 merupakan presentase dari tanggapan partisipan mengenai ancaman radikalisme di dunia pendidikan yaitu $63,2 \%$ mengalami kekerasan di seklah secara fisik dan 
Implementasi Bela Negara di Era Teknologi Dalam Pembelajaran Pendidikan Kewarganegaraan, Auli Ihza Ahyati, Dinie Anggraeni Dewi

mental serta terjadinya bulying. 31,6\% mengatakan bahwa tawuran antar pelajar merupakan aksi yang mengancam radikalisme didunia pendidikan serta 5,3\% berpendapat lunturnya sopan santun antar manusia.

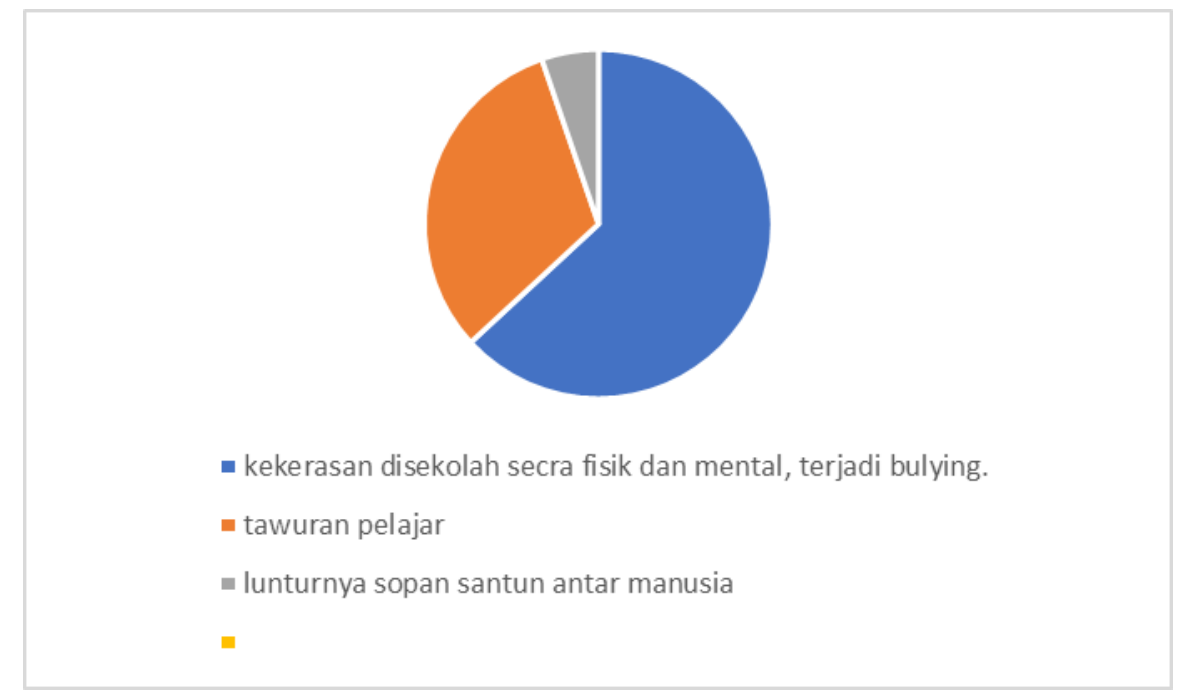

Gambar 2. Diagram kuisioner

Menurut Dwi Hartono (2020:41) menyatakan bahwa "ancaman nyata terhadap radikalisme didunia pendidikan adalah sebagai berikut :

a. $84 \%$ siswa pernah mengalami kekerasan di sekolah secara fisik dan mental.

b. Sebanyak $75 \%$ sekolah pernah mengakui bahwasanya terjadi kekerasan pada sekolah tersebut.

c. $22 \%$ peserta didik mengatakan pelaku dari kekerasan adalah berasal dari guru serta petuas sekolah lainnya.

d. $40 \%$ siswa penah merasakan kekerasan fisik yang dilakukan oleh teman sebayanya.

e. $50 \%$ anak pernah mengalami bulying di sekolah.

f. $48.9 \%$ siswa setuju akan radikalisme di sekolah.

Pada penelitian ini teknologi sangat berpengaruh bagi jiwa bela negara masyarakat indonesia sehubungan bela negara yang sangat berhubungan erat dengan ketahanan nasional. Lunturnya sikap bela negara pada masyarakat akan mengancam ketahanan nasional bangsa. Teknologi sendiri dapat membawa pengaruh negatif, pengaruh tersebut salah satunya melalui sosial media dimana hampir seluruh masyarakat menggunakan sosial media baik dalam kebutuhan berkomunikasi maupun urusan pekerjaan. Penelitian yang menyebarkan kuesioner kepada 20 partisipan ini menyebutkan bahwa $78,9 \%$ setuju bahwa sosial media banyak membawa dampak negatif bagi ketahanan nasional. Pengaruh negatif yang disebutkan adalah menyebarnya berita HOAX sehingga informasi yang didapatkan tidak valid dan adanya kekelruan informasi yang membuat kesalah pahaman. Adanya penyebar paham radikalisme, seeta perdagangan narkoba yang dilakukan melalui sosial media. 
Tabel 1. Deskripsi Kuisioner.

\begin{tabular}{|l|c|c|}
\hline \multicolumn{1}{|c|}{ Keterangan } & Jumlah & Presentase \\
\hline $\begin{array}{l}\text { Mahasiswa Universitas } \\
\text { Bhayangkara Surabaya }\end{array}$ & 3 & $15,8 \%$ \\
\hline Mahasiswa UPI kampus cibiru & 10 & $60 \%$ \\
\hline Universitas Airlangga & 3 & $8,4 \%$ \\
\hline Masyarakat umum & 4 & $15,8 \%$ \\
\hline
\end{tabular}

Pada tabel 1. deskripsi kuisioner terdapat $68,4 \%$ responden menyatakan setuju bahwa sosial media membawa dampak negatif bagi ketahanan nasional dan menyebabkan lunturnya rasa bela negara dalam setiap pribadi. Namun, terdapat 31,6\% partisipan menjawab bahwa tidak setuju, karena sosial sendiri banyak membawa dampak positif dalam memajukan bangsa dan negara Indonesia. Sebanyak 78,9\% juga menjawab bahwa dampak negatif dari sosial media adalah ideologi, radikal bebas, perdagangan narkoba, masuknya budaya asing. Sebanyak 15,8\% partisipan menyatakan bahwa dampak negatif dari sosial media adalah bermain game, menurunkan mental anak karena game tersebut serta, candu dalam bermain gadget. 5,3\% partisipan menjawab dampak dari sosial media adalah tidak disiplin waktu.

21,1\% menyebutkan bahwa sosial media tidak berpengaruh atau tidak membawa dampak negatif bagi ketahanan nasional. Partisipan beranggap karena sosial media membawa dampak positif seperti informasi-informasi terbaru dan perkembnagan teknologi yang semakin maju.

Kemajuan teknologi pada saat ini membawakan dampak negatif yang paling signifikan dan terasa dalam kehidupan, yaitu : Pertama, ancaman pelanggaran hak kekayaan intelektual HKI, karena mudahnya dalam mengakses informasi serta menyebabkan maraknya plagiarisme. Kedua, ancaman terhadap pikiran pada pribadi anak yang cenderung lebih bepikir praktis namun tidak kritis. Ketiga, menurunnya moralitas pada anak sehingga terjadinya tindak kejahatan kriminalitas. Keempat, tidak dapat memanfaatkan waktu yang disediakan, seperti waktu belajar siswa yang cederung anak lebih suka bermain game online (Wawan, 2017).

Pada penelitian ini sebagian besar responden menganggap bahwa sikap jiwa bela negara masyarakat saat ini kurang terdapat 52,6\% yang menganggap sikap bela negara masyarakat aat ini kurang, karena banyaknya masyarakat yang tidak mematuhi aturan negara sendiri, masuknya berita hoax dan paham radikalisme yang mengancam ketahanan dan keutuhan bangsa. Namun 36,8\% menganggap bahwa jiwa bela negara saat ini sudah cukup dalam pengimplementasinya. 10,9\% menganggap bahwa jiwa bela negara saat ini sudah baik dan terlaksanan sebagaiman mestinya. Berbagai implementasi bela negara yang dilakukan adalah patuh terhadap peraturan yang berlaku, 
menggunakan produk lokal, menciptakan suasana rukun, harmonis antar masyarakat, membela hak asasi manusia, hidup ber toleransi dan mengamalkan sila atau dasar ideologi bangsa.

Pada penelitian yang sudah dilakukan dengan menyebar kuisioner terhadap 20 partisipan, 100\% menganggap bahwa pendidikan kewarganegaraan sangat diperlukan dalam meningkatkan jiwa bela negara agar dapat di implementasikan di kehidupan sehari-hari. Dalam berbagai permasalahan serta ancaman yang ada pada era teknologi ini tentunya diperlukan peranan pembelajaran pendidikan kewarganegaraan terhadap peserta didik maupun warga negara. Berikut permasalahan yang ada menurut (Nurmalisa..Y. A. mentari, Rohman, 2020), serta bagaimana implementasi kesadaran bela negara dalam memperkokoh ketahanan nasional.

Belum optimalnya kurikulum yang saat ini dilaksanakan dan pembinaan bela negara di era teknologi, menurunya tingkat kesadaran bela negara dan rasa cintah tanah air tentunya disebabkan karna dihapusnya mata pelajaran Pendidikan Moral Pancasila (PMP), hal yang harus dan dapat kita lakukan untuk menumbuhkan kembali rasa cinta tanah air dan kebangsaan yaitu dengan mengembalikan mata pelajaran tersebut, meningkatkan siswa dalam memahami pembelajaran pendidikan kewrganegaraan. Implementasi lain yang dapat dilakukan bela negara disekolh adalah, menerapkan sila-sila pancasila, mengikuti peraturan di sekolah, menyanyikan lagu indonesia raya.

Rendahnya kesadaran bela negara pada genersi milenial di era teknologi. Kesadaran bela negara bagi kalangan milenial saat ini masi rendah, sikap kurang peduli terhadap sesama, dan rasa tangun jawab serta keinginan untuk memajukan bangsa. Hal tersebut dapat mengancam ketahanan sistem negara. Dalam permasalahan ini belum ada atau jarang ditemukan metode pembelajaran untuk mengimplementasikan agar dapat mengatasi ancaman dan permasalahan tersbut, namun implementasi yang dapat dilakukan adalah memperkuat ideologi peserta didik terhadap empat pilar kebangsaan yaitu pancasila, UUD NKRI, dan kesadaran bhineka tunggal ika. Perlunya kurikulum pendidikan kewarganegaraan dalam pembinaan bela negara bagi bangsa.

Belum sinergisnya kementerian Lembaga dan Pemerintahan daerah dalam Pelaksanan matei pembinaan kesadaran bela negara. Dalam pelaksanaan pembinaan kesadaran bela negara ini tentunya masih rendah karena koordinasi yang dijalankan belum bejlan dengan sempurna dan cenderung berjalan sendiri, kegiatan penerapan bela negara ini tidakboleh dilakukan secara monopoli, oleh kementerian maupun lembga negara apapun. Bela negara dalam pertahanan mengacu pada semangat jiwa seluruh anak bangsa. Implementasi bela negara tidak hanya dilakukan dalam egiatan wajib militer namun bela negara mencakup semua bidang. Sebagai anak bangsa implementasi bela negara yang dpat dilakukan adalah melakukan pendidikan dengan benar, memahami tujuan dari adanya ideologi bangsa serta mengendalikan atau menyaring setiap informasi.

Menurut (Sutarman, 2011: 82) Konsep bela negara sendiri dibagi menjadi dua yaitu secara fisik dan non fisik. Pertama yaitu, bela negara fisik yang dilakukan untuk menghadapi ancaman dari luar, sedangkan bela negara secara nonfisik yaitu dapat diartikan sebagai upaya untuk mempertahankan kesatuan dan ketuhan Republik Indonesia, dengan meningkatkan sikap kebangsaan 
dan menanamkan rasa kecntan terhadap negara dengan cara ikut serta berperan akif dalam memajukan kesejahteraan bangsa. Bela negara nonfisik merujuk pada Undang-Undang No.3 tahun 2002, yaitu keikutsertaan warga negara dalam bela negara diselengggarakan melalui pendidikan kewarganegaraan. (Suryatni, 2019: 53), Peranan kita sebagai warga negara bangsa dalam bela negara nonfisik ini sangat diperlukan, bahkan sebenarnya bela negara nonfisik ini bisa kita lakukan dengan mudah dan melekat pad kehidupan sehari-hari. Disebutkan beberapa bentuk kegiatan yang dapat dilakukan oleh warga negara dalam meng implementasikan sikap bela negara yaitu :

a. Meningkatkan kesadaran berbangsa dan bernegara pada diri sendiri, termasuk dalam menghayati demokrasi, menerima perbedan pendapat.

b. Berperan aktif dalam memajukan bangsa dan negara dengan memberikan karya nyata bukan hanya sebuah retorika.

c. Kesadaran dan kepatuhan atas dasar ideologi bangsa, dan menjunjung tinggi hak asasi manusia.

d. Pembekalan mental spiritual diperlukan untuk warga negara agar dapat menyaring budayabudaya luar yang tentunya membawa dampak negatif bagi kehidupan.

Terdapat upaya masyarakat dalam menggunakan sosial media agar tidak hanya memberikan dampak negatif namun memberikan dampak yang positif bagi bela negara di Indonesia yaitu, 20 partisipan menyatakan upaya dengan cara menggunakan media sosial dengan sebijak mungkin, menyebarkan informasi yang valid dan tidak termakan hoax, mempelajari sosial media untuk hal hal yang positif, masyarakat sendiri mampu memanfaatkan sosial media untuk meberikan edukasi, membuat salah satu media yang bisa memberikan pemahaman tentang ketahanan negara kepada masyarakat melalui postingan yang sederhana dan tidak terlalu mengikuti apa yang sedang trending.

Beberapa unsur dasar negara yang apat kita implementasikan dan lakukan dalam keidupan sehari-hari yaitu: Pertama, cinta tanah air, hal ini dapat dilakukan dengan cara menjaga serta merawat bagsa ini dari ancaman yang ada. Menjaga diri agar tidak melakukan suatu kesalahan yang dapat memalukan nama bangsa. Kedua, kesadaran berbangsa dan bernegara hal ini dapat dilakukan dengan memberikan bakti atau memberikan prestasi untuk berkontribusi daam negara. Ketiga, meyakinkan diri pada ideologi bangsa yaitu mengamalkan pancasila dalam setiap silanya, serta menyadari bahwa ideologi ini memiliki fungsi untuk menyatukan perbedaan setiap warganya. Keempat, rela berkorban untuk bangsa yaitu lebih mementingkan urusan bangsa daripada pribadi. Kelima, memiliki kemampuan awal bela negara.

Contoh-contoh bela negara

1. Melestarikan budaya

2. Belajar dengan raji bagi para penerus bangsa dengan ini dapat meningkatkan sumber daya manusia.

3. Memberikan contoh atau perilaku yang menunjukan kebaikan namun harus sesuai peraturan dan ideologi bangsa

4. Berprestasi sesuai keahlian merupakan salah satu kontribusi untuk mengharumkan nama bangsa. 
5. Taat akan hukum dan aturan aturan negara dengan cara tidak melanggar hukum yang ada contohnya membayar pajak engan benar dan tepat waktu.

Wujud bela negara dalam Muawanah (Sutarman, 2011) menyatakan “ kegiatan yang dapat dilakukan oleh setiap wargannya. Adapun beberapa kegiatan yan dapat dilakukan dalam mewujudkan bela negara di lingkungan keluarga, lingkungan sekolah dan lingkungan masyarakat. Contoh bela negara di lingkungan keluarga adalah dengan memahami adanya hak dan kewajiban yang harus dilakukan pada setiap anggota keluarga dan berfungsi untuk menjaga keutuhan keluarga. Bela negara di lingkungan sekolah dlakukan dengan mematuhi setiap aturan yang ada dalam lingkungan sekolah, bertutur kata yang baik serta bersikap sesuai aturan, bertanggung jawab atas tugas yang didapati. Bela negara dalam lingkungan masyarakat, dilakukan dengan ikut berperan aktif dalam setiap kegiatan kemasyarakatan, rela untuk berkorban demi keutuhanwarga negara atau rakyatnya, melestarikan setiap adan dan budaya yang sudah diterapkan masyarakat.

Pentingnya bela negara bagi bagi kemajuan bangsa dilakukan untuk mempertahankan kedaulatan rakyat. Landasan mengapa bela negara wajib untuk dilakukan setiap warga adalah menjaga kedaulatan bangsa, wujud rasa terimakasih warga, menciptakan ketentraman dan keamanan bagi lingkungan sekitar dan melestarikan kebudayaa yang sudah ada sejak jaman penjajahan.

\section{KESIMPULAN}

Setiap warga negara sebetulnya memilik hak dan kewajiban dalam melaksanakan bela negara. Bela negara adalah suatu rasa yang dimiliki masyarakat untuk mempertahankan kemanan negara ini, sikap yang dilakukan dan dilandasi dengan rasa cinta tanah air, kesadaran berbangsa dan bernegara serta mampu menghadapi setiap ancaman yang datang baik dari dalam negara maupun luar, tentunya ancaman tersebut dapat merusak keutuhan bangsa.

Pendidikan kewarganegaraan dalam upaya bela negara memiliki peran penting yaitu menjadikan warga negara yang baik, mampu mendukung masa depan bangsa dan negara. Berbagai cara digunakan untuk meningkatkan rasa cinta tanah air pada bangsa Indonesia serta Implikasi apa yang dapat dilakukan dalam menghadapi setiap masalah yang ada pada negara ini. Impikasi atau penerapan bela negara sangat diperlukan bagi bangsa ini terutama generasi muda di era teknologi dimana tekknologi sendiri membawa dampak negatif yang dapat merusak keutuhan dan ketahanan bangsa.

Pemerintah sendiri sudah melakukan berbagai upaya agar pelaksanaan atau implikasi dari bela negara tercapai dengan cara melalui pendidika kewarganegaraan yang kini sudah menjadi mata pelajaran wajib bagi setiap kelasnya. Pemerintah juga telah mengeluarkan cara serta regulasi dalam menangani masalah menurunya sikap bela negara pada generasi saat ini. Upaya dan tugas negara kini menjadi kewajiban bagi seluruh wargannya, bukannlah hanya ditugaskan kepada aparat keamanan negara dalam menangkal tantangan paham radikalisme. 


\section{UCAPAN TERIMAKASIH}

Terimakasih saya ucapkan kepada teman-teman mahasiswa dari berbagai universitas yang telah membantu mengisikan dan menjawab beberapa pertanyaan dari saya. Terimakasih juga saya ucapkan kepada kakak editor yang telah membimbing dan mengarahkan saya dalam menyelesaikan artikel ini sampai lolos dalam seleksi dandapat di publish . tanpa dukungan dan dorongan dari seluruh pihak tidak mungkin saya dapat menyelesaikan tugas ini dengan sempurna.

\section{DAFTAR PUSTAKA}

Asep., dkk. . (2020). Pendidikan Pendahuluan Bela Negara melalui Pendidikan Kewarganegaraan. Jurnal Civics, Vol 17. No 2.

Bagus, W. . (2006). Pendidikan Kewarganegaraan Bela Negara. . Pendidikan Pembangunan Karakter Bangsa, Universitas Udayana.

Endang, K. . (2019). Peran Pendidikan Kewarganegaraan Dalam Menghadapi Revolusi 4.0. Vol 6. No 1.

Farida, S. (2017). Eksistensi Pendidikan Kewarganegaraan di Perguruan Tinggi dalam Memperkokoh Karakter Bangsa Indonesia. Junal Kependidikan Dasar. Vol 2. No 1.

Gerdinand, D. (2017). Application of state defense education in colleges. Strategi Pertahanan Darat, . Vol 3. No 1. hal 1-27.

Hartono, D. (2020). Fenomena KEsadaran Bela Negara di Era digital Dalam Perspektif Ketahanan Nasional. Jurnal Kajian Lemnasham, Edisi 14.

Kris W, Muhammad Fahrid. (2018). Konsep Bela Negara Dalam Perspektif Ketahanan Nasional. Jurnal hukum dan pembangunan, Vol 43. No 3.

Mukhtadi, Maghda Komala. (2018). Membangun Kesadaran Bela Negara Bagi Generasi Milenial dalam Sistem Pertahanan Nasional. Manajemen Pertahanan. Vol 4. No 2.

Muwamanah. (2017). Implementasi Bela Negara di Lingkungan Mahasiswa Sebagai Upaya Menangkal Radikalisme.

Nurmalisa Y. Ana mentari, Rohman. (2020). Peranan Pembelajaran Pendidikan Kewarganegaraan Dalam Membangun Civics Consience. Vol 07. No 1.

Septiana, T. (2020). Pembelajaran Bela Negara Dalam PenPembelajaran Bela Negara Dalam Pedidikan Kewarganegaraan Sebagai Upaya Membina Semangat Nasionalisme Mahasiswa. Jurnal Kajian Pendidikan Umum, Vol 18. No 2.

Suharyanto, A. (2013). Peranan Pendidikan Kewarganegaraan Dalam Membina Sikap Toleransi Antar Siswa. Jurnal Ilmu Pemerintahan dan Sosial Politik UMA, Vol 1. No 2. Hal 192-203.

Suryatni, L. (2019). Bela Negara Sebagai Pengejawantahan dalam Ketahanan Nasional Berdasarkan UUD 1945. Jurnal Ilmiah Hukum Dirgantara, Vol 1. No 1.

Sutarman. (2011). Persepsi dan Pengertian Pembelaan Negara Berdasarkan UUD 1945 (Amandemen). Jurnal Magista, No 75. hal 81-94. 
Implementasi Bela Negara di Era Teknologi Dalam Pembelajaran Pendidikan Kewarganegaraan, Auli Ihza Ahyati, Dinie Anggraeni Dewi

Suwarno, W. (2011). Implementasi Bela Negara Untuk Mewujudkan Nasionalisme. Jurnal Ilmiah Civics, Vol 1 No 1. 18-31.

Wahab, A Aziz. Sapriya. (2012). Teori Landasan Pendidikan Kewarganegaraan. Bandung: Alfabeta.

Wawan, S. (2017). Era Digital dan Tantangannya. Universitas Pendidikan Indonesia. 